\title{
Distribution, prevalence and severity of Parvicapsula minibicornis infections among anadromous salmonids in the Fraser River, British Columbia, Canada
}

\author{
Simon R. M. Jones ${ }^{1, *}$, Gina Prosperi-Porta ${ }^{1}$, Sheila C. Dawe ${ }^{1}$, David P. Barnes ${ }^{2}$ \\ ${ }^{1}$ Fisheries and Oceans Canada, Pacific Biological Station, 3190 Hammond Bay Road, Nanaimo, \\ British Columbia V9T 6N7, Canada \\ ${ }^{2}$ Fisheries and Oceans Canada, Cultus Lake Laboratory, Cultus Lake, British Columbia V2R 5B6, Canada
}

\begin{abstract}
Polymerase chain reaction (PCR) and microscopic examination of stained kidney sections were used to diagnose infections with the myxozoan parasite Parvicapsula minibicornis in maturing Fraser River salmon. In 2 series of collections, the parasite was detected in 109 of 406 migrating sockeye salmon Oncorhynchus nerka belonging to Early Stuart, Early Summer and Summer run-timing groups, mainly upper Fraser River stocks. However, the parasite was detected neither in fish at sea nor once they had migrated several $100 \mathrm{~km}$ upstream. Prevalence then increased to $95 \%$ or greater at the spawning grounds. Histological examination of kidney was less sensitive than PCR in detecting the parasite in salmon collected from the earliest sites in both collections found positive by PCR. Severity of infection was greatest at the spawning grounds. Development of infection in sockeye, measured by prevalence, severity or by the rate of false-negative histological diagnoses, appeared to be a useful estimate of in-river residence time. Prevalence and severity of infections in sequential samples of Harrison River and Weaver Creek sockeye stocks collected from the Harrison River indicated that more time had elapsed since parasite transmission than would be predicted based on migration distance alone. Pink salmon Oncorhynchus gorbuscha, coho salmon $O$. kisutch and chinook salmon $O$. tshawytscha were found to be infected with the parasite. Development of $P$. minibicornis in pink salmon was most similar to that in sockeye. Pink and coho salmon may be at risk to the pathological consequences of $P$. minibicornis infection.
\end{abstract}

KEY WORDS: Parvicapsula minibicornis - Oncorhynchus nerka · Fraser River · Histology · Polymerase chain reaction

Resale or republication not permitted without written consent of the publisher

\section{INTRODUCTION}

Sockeye salmon Oncorhynchus nerka that spawn in tributaries of the Fraser River, British Columbia, Canada, are classified into 4 run-timing groups according to the timing of their spawning migration in freshwater, i.e. Early Stuart, Early Summer, Summer, Late. Each run-timing group is further divided into stocks, based on the nursery stream or lake of origin. Parvicapsula minibicornis is a myxozoan parasite of
Fraser River sockeye that matures within glomerular capillaries (Kent et al. 1997, St-Hilaire et al. 2002). In severe infections, developmental stages and mature spores also occur within the renal tubules. Glomerulonephritis that is characterised by diffuse thickening of the basement membrane, occlusion of the glomerular capillaries and necrosis of the tubular epithelium is associated with severe infection (Raverty et al. 2000). This renal pathology has focused attention on the role of the parasite in elevated prespawn mortality recently 
observed among certain stocks of Late run-timing Fraser River sockeye (St-Hilaire et al. 2002).

Surveys for the parasite were conducted among several Fraser River stocks of sockeye salmon in 1999 and 2000 by using histological analysis and polymerase chain reaction (PCR) (St-Hilaire et al. 2002). While no evidence of Parvicapsula minibicornis was found in adults prior to river entry or shortly thereafter, prevalence increased during the upriver migration and ranged from 48 to $100 \%$ among all stocks examined at or near the spawning grounds. In addition, the parasite did not occur in juvenile salmon collected from nursery streams and lakes but was detected in sockeye smolts of Fraser River origin collected in the Strait of Georgia (St-Hilaire et al. 2002). This suggested that transmission occurred at or near the river estuary and that adult

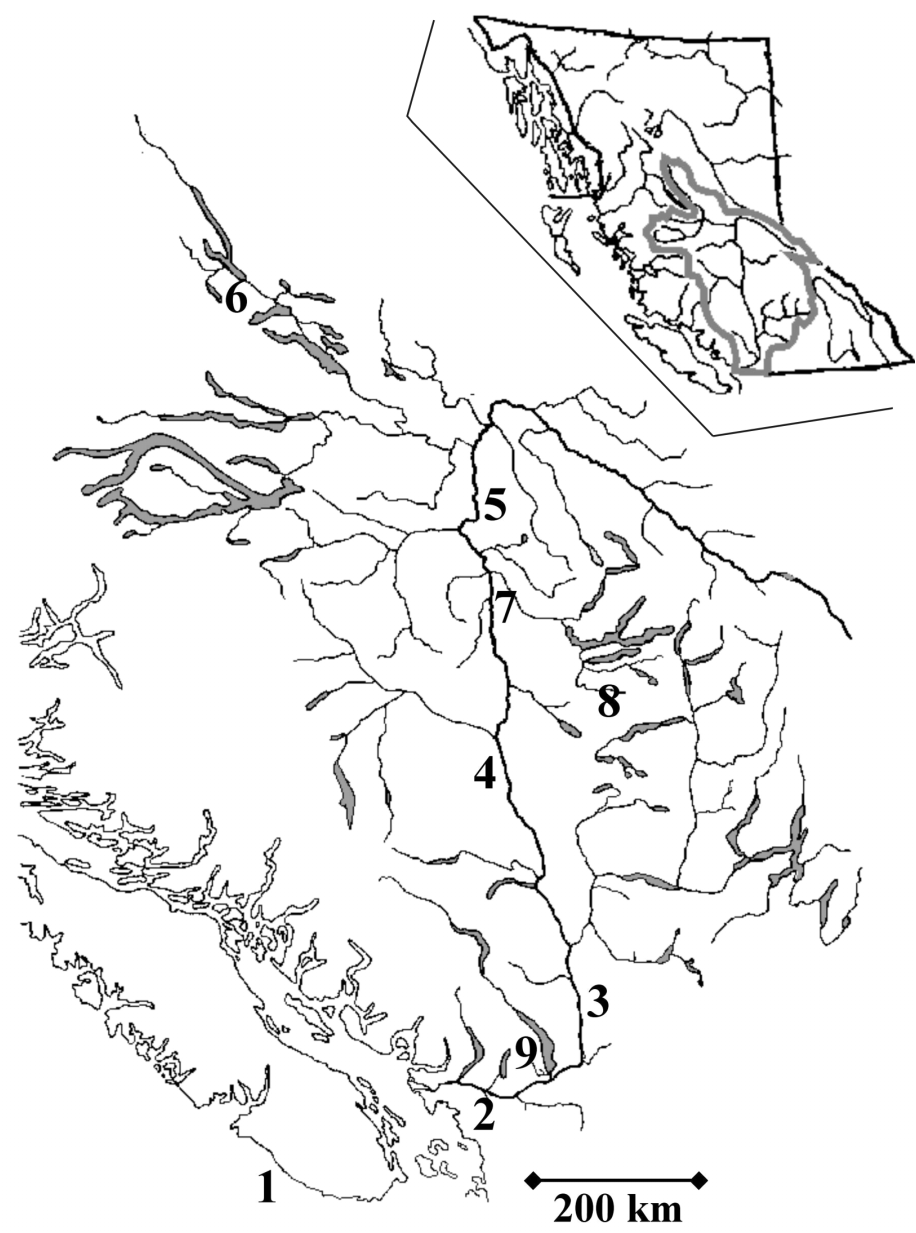

Fig. 1. Map of the Fraser River drainage basin showing marine and freshwater sockeye sampling sites: (1) Port Renfrew; (2) Whonnock; (3) Yale and Hell's Gate; (4) Churn Creek; (5) Stoner; (6) Gluskie Creek; (7) Quesnel River; (8) Lower Horsefly River and McKinley; (9) Harrison River and Weaver Creek and juvenile salmon acquired the infection as they migrated through this site. All species of Parvicapsula have been reported from marine or anadromous fish (Shulman 1953, Kabata 1962, Evdokimova 1977, Kovaleva \& Gaevskaya 1981, Hoffman 1984, Lester \& Sewell 1989, Landsberg 1993, Padma-Dorothy \& Kalavati 1993, Kent et al. 1997, Zhao et al. 2000). A hypothesis of estuarine transmission would therefore be consistent with the location of an intermediate host that occupies a marine or brackish water habitat and would explain the widespread distribution of the parasite throughout the Fraser River drainage basin. The objectives of the present study were 2-fold: to further describe the relationship between freshwater migration and the prevalence and severity of $P$. minibicornis infections in adult Fraser River sockeye salmon and to document the occurrence of the parasite in new host species.

\section{MATERIALS AND METHODS}

Collection of fish. Surveillance of migrating adult sockeye was conducted over 3 collections in 2001 (see map, Fig. 1). In the first 2 (June to July and July to September), fish were collected prior to river entry from a Pacific Salmon Commission test fishery at Port Renfrew, off the west coast of Vancouver Island, British Columbia and at several in-river sites leading up to and including the nursery streams. In the third (August to October), 7 sets of samples were collected from 1 location on the Harrison River, a tributary of the Fraser River, and 2 sets from the Fisheries and Oceans Canada (FOC) spawning channel at Weaver Creek, a tributary of the Harrison River. Collections were also made of sexually mature pink salmon Oncorhynchus gorbuscha from the mainstem Fraser River, recently spawned chinook salmon $O$. tshawytscha and sexually mature, pre- and post-spawned coho salmon $O$. kisutch held at FOC enhancement hatcheries in the Fraser River drainage basin.

Samples of posterior kidney and gill were dissected from freshly dead specimens and placed immediately into $95 \%$ ethanol. Samples of anterior and posterior kidney, gill, heart and liver were also fixed in Davidson's solution (Humason 1979) for histological assessment. One scale was collected from above the lateral line of each fish for stock identification (Gable \& CoxRogers 1993).

PCR. DNA was extracted from approximately $25 \mathrm{mg}$ of ethanol-fixed kidney using the method of St-Hilaire et al. (2002). The primers and conditions under which the PCR was run were as described by St-Hilaire et al. (2002) and the reaction amplified a $1091 \mathrm{bp}$ fragment of the Parvicapsula minibicornis 18S rRNA gene. 
Histological assessment. Tissues were processed for routine histological examination and duplicate $5 \mu \mathrm{m} \mathrm{sec}-$ tions, mounted on glass slides were stained with a modified Pappenheim (MP) stain (Humason 1979) or with haematoxylin and eosin (H\&E), respectively. Tissues initially fixed in $95 \%$ ethanol for PCR were post-fixed in Davidson's solution and also processed for histology as described above. The severity of infections at each collection site was estimated from the mean number of infected glomeruli per 25 glomeruli examined in MPstained histological sections from infected fish.

\section{RESULTS}

Parvicapsula minibicornis was detected by PCR in 49 of $242(20.2 \%)$ sockeye from the first collection. Racial analysis indicated that these fish belonged to the Early Stuart and Early Summer run-timing groups. The parasite was also detected in 60 of 164 (36.6\%) sockeye from the second collection, found to be Summer runtiming sockeye. The parasite was first detected in these groups by using PCR, following upriver migrations of 440 and $619 \mathrm{~km}$, respectively (Table 1). Thereafter, the prevalence increased to $95 \%$ or greater at the spawning grounds. Kidney was considered infected with $P$. minibicornis when parasite stages were identified within stained glomeruli using light microscopy. The parasite stages were more clearly evident in kidney sections stained with MP than in those stained with H\&E. In both collections, significantly fewer infections were detected by histology than by PCR at downstream sites where salmon were first found to be infected $\left(\chi^{2}=10.99, \mathrm{p}<0.001\right.$ and $\chi^{2}=7.06, \mathrm{p}<0.01$, respectively). In the Early Stuart/Early Summer groups, these false-negative histological results occurred in 11 of 13 PCR-positive samples at $440 \mathrm{~km}$ and in 1 of 18 at $718 \mathrm{~km}$. In the Summer group, falsenegative histological results occurred in 6 of $20 \mathrm{PCR}$ positive samples at $619 \mathrm{~km}$, in 2 of 20 at $750 \mathrm{~km}$ and in 1 of 21 samples at $805 \mathrm{~km}$ (Table 1). In contrast, myxozoan infections within glomeruli were observed in 2 samples $(718 \mathrm{~km}$, Early Stuart and Early Summer groups; 805 km, Summer group) in which P. minibicornis infections were not detected by PCR. In all other samples, histological diagnoses agreed with those obtained using PCR. The severity of infections ranged from 1.0 to 21.4 in the first and from 4.6 to 12.6 in the second collection (Table 1). In both groups, the severity of infection increased with distance migrated upstream and was greatest at the spawning grounds.

Most sockeye collected from the Harrison River belonged to the Harrison River $(n=52)$ or Weaver Creek $(n=66)$ stocks (Table 2). Of the remaining sockeye, 3 belonged to the Birkenhead River stock and 3 were unclassifiable. All 40 salmon in 2 collections from the spawning channel belonged to the Weaver Creek stock. Only 1 of 16 sockeye collected in the first 2 sets was of Weaver Creek stock. Parvicapsula minibicornis was detected in Harrison River sockeye in all sample sets but was not detected in Weaver sockeye until the fourth sample set. The overall prevalence by PCR (by histology) was $76.9 \%$ (65.4\%) in Harrison River stock and $63.6 \%(56.1 \%)$ in Weaver stock sockeye collected from the Harrison River (Table 2). The mean severity in Weaver stock sockeye collected from the Harrison

Table 1. Parvicapsula minibicornis in 3 run-timing groups of adult Fraser River sockeye salmon Oncorhynchus nerka in 2001. Distance: $\mathrm{km}$ upstream from the mouth of the Fraser River. Date: date of collection. PCR: (sample size) of kidney samples from which $1091 \mathrm{bp}$ product was amplified. Histology: (sample size) of kidney samples with recognizable P. minibicornis. Severity: mean number of affected glomeruli per 25 glomeruli examined from infected fish (sample size)

\begin{tabular}{|c|c|c|c|c|c|}
\hline \multirow{2}{*}{$\begin{array}{l}\text { Run-timing group } \\
\text { Location }\end{array}$} & \multirow{2}{*}{$\begin{array}{l}\text { Distance } \\
(\mathrm{km})\end{array}$} & \multirow{2}{*}{$\begin{array}{c}\text { Date } \\
(\mathrm{d} / \mathrm{mo})\end{array}$} & \multicolumn{2}{|c|}{ Prevalence } & \multirow{2}{*}{ Severity } \\
\hline & & & PCR (\%) & Histology $(\%)$ & \\
\hline \multicolumn{6}{|c|}{ Early Stuart/Early Summer } \\
\hline Port Renfrew & - & $30 / 6$ & $0(29)$ & $0(29)$ & $0(29)$ \\
\hline Whonnock & 50 & $05-6 / 7$ & $0(61)$ & $0(27)$ & $0(27)$ \\
\hline Yale & 170 & $09-10 / 7$ & $0(51)$ & $0(27)$ & $0(27)$ \\
\hline Hell's Gate & 200 & $12-14 / 7$ & $0(41)$ & $0(23)$ & $0(23)$ \\
\hline Churn Creek & 440 & $18-19 / 7$ & $65(20)$ & $10(20)$ & $1.0(20)$ \\
\hline Stoner & 718 & $25 / 7$ & $95(20)$ & 95 (19) & 3.9 (19) \\
\hline Gluskie Creek & 1086 & $31 / 7$ & $100(20)$ & $100(20)$ & $21.4(20)$ \\
\hline \multicolumn{6}{|l|}{ Summer } \\
\hline Port Renfrew & - & $28 / 7$ & $0(23)$ & $0(23)$ & $0(23)$ \\
\hline Whonnock & 50 & $10 / 8$ & $0(40)$ & $0(24)$ & $0(24)$ \\
\hline Hell's Gate & 200 & $15 / 8$ & $0(40)$ & $0(27)$ & $0(27)$ \\
\hline Quesnel River & 619 & $24 / 8$ & $100(20)$ & $70(20)$ & $4.6(20)$ \\
\hline Lower Horsefly River & 750 & $28 / 8$ & $100(20)$ & $90(20)$ & $5.1(20)$ \\
\hline McKinley Creek & 805 & $05 / 9$ & $95(21)$ & $95(21)$ & $12.6(21)$ \\
\hline
\end{tabular}


Table 2. Prevalence and severity of Parvicapsula minibicornis in adult sockeye salmon Oncorhynchus nerka migrating in the Harrison River and Weaver Creek in 2001. Date: date samples collected. The first 7 collections were made at 1 location on the Harrison River. Collections of $4 / 10$ and 15/10 were made at the Weaver Creek spawning channel. Stock: determined by scale analysis. PCR: number of posterior kidney samples from which 1091 bp product was amplified. Histology: number of posterior kidney samples with $P$. minibicornis. Severity: mean number of affected glomeruli per 25 glomeruli examined from infected fish

\begin{tabular}{|c|c|c|c|c|c|}
\hline \multirow{2}{*}{$\begin{array}{l}\text { Date } \\
\text { (d/mo) }\end{array}$} & \multirow[t]{2}{*}{ Stock } & \multirow{2}{*}{$\begin{array}{c}\text { Sample } \\
\text { size }\end{array}$} & \multicolumn{2}{|c|}{ Prevalence } & \multirow[t]{2}{*}{ Severity } \\
\hline & & & $\begin{array}{l}\text { PCR } \\
(\%)\end{array}$ & $\begin{array}{c}\text { Histology } \\
(\%)\end{array}$ & \\
\hline \multirow[t]{2}{*}{ 17/08 } & Harrison & 7 & 3 (42.9) & 3 (42.9) & 3.3 \\
\hline & Weaver & 0 & - & - & - \\
\hline \multirow[t]{2}{*}{ 20/08 } & Harrison & 8 & 5 (62.5) & 5 (62.5) & 7.4 \\
\hline & Weaver & 1 & 0 & 0 & - \\
\hline \multirow[t]{2}{*}{$30 / 08$} & Harrison & 7 & $6(85.7)$ & $4(57.1)$ & 5.0 \\
\hline & Weaver & 7 & 0 & 0 & - \\
\hline \multirow[t]{2}{*}{ 06/09 } & Harrison & 12 & $8(66.7)$ & $8(72.7)^{\mathrm{a}}$ & 8.4 \\
\hline & Weaver & 9 & $3(33.3)$ & $1(12.5)$ & 5.0 \\
\hline \multirow[t]{2}{*}{ 13/09 } & Harrison & 4 & 4 (100) & 4 (100) & 11.3 \\
\hline & Weaver & 16 & $9(56.3)$ & $8(50.0)$ & 17.1 \\
\hline \multirow[t]{2}{*}{ 20/09 } & Harrison & 3 & 3 (100) & 3 (100) & 7.0 \\
\hline & Weaver & 19 & $16(84.2)$ & $16(84.2)$ & 22.5 \\
\hline \multirow[t]{2}{*}{$27 / 09$} & Harrison & 11 & $11(100)$ & $7(63.6)$ & 5.4 \\
\hline & Weaver & 14 & $14(100)$ & $12(85.7)$ & 18.7 \\
\hline \multirow[t]{2}{*}{$04 / 10$} & Harrison & 0 & - & - & - \\
\hline & Weaver & 20 & 20 (100) & 20 (100) & 20.3 \\
\hline \multirow[t]{2}{*}{$15 / 10$} & Harrison & 0 & - & - & - \\
\hline & Weaver & 20 & 20 (100) & 20 (100) & 20.1 \\
\hline
\end{tabular}

River was 19.5 (range 5.0 to 22.5) and in Harrison River stock sockeye was 7.0 (range 3.3 to 11.3). The parasite was detected in all 40 sockeye collected in 2 sets from the spawning channel with mean severities of 20.3 and 20.1, respectively (Table 2). Myxozoan infections within the glomeruli were observed in 1 sample
(Harrison stock) in which $P$. minibicornis was not detected by PCR.

Parvicapsula minibicornis was detected by PCR in 19 of $20(95 \%)$ spawning pink salmon from the Fraser River near Chilliwack, in all 30 (100\%) spawning coho salmon from 3 sites and in 21 of 40 (53\%) spawning chinook salmon from 2 sites within the Fraser River drainage basin (Table 3). The prevalence of the parasite, determined histologically, was $85 \%$ in pink salmon, $66 \%$ in coho salmon, $0 \%$ in 1 chinook salmon sample and $20 \%$ in the second sample (Table 3). PCR analysis failed to detect the parasite in 3 of 4 chinook samples with histological evidence of infection in glomeruli. The severity of infections in spawning pink, coho and chinook salmon was considerably lower than those measured in spawning sockeye salmon (Table 3).

\section{DISCUSSION}

Parvicapsula minibicornis infections were detected in the kidney of sockeye salmon using PCR. While not quantitative, this method was shown to be specific for P. minibicornis and more sensitive in detecting the parasite than histological examination (St-Hilaire et al. 2002). Histological examination of kidney sections, stained with a MP stain (Humason 1979), were used here, however, to quantitate the severity of infection and to document how severity changed during the freshwater migration of adult salmon. The detection of $P$. minibicornis using PCR concurred with that obtained using histological examinations in most specimens. Despite this, it was not always possible to confirm the identity of sporoblasts and plasmodia observed in the glomeruli, tubules or renal interstitium. Thus, myxozoan infections were observed within glomeruli in a total of 3 sockeye samples that were negative by PCR, indicating either infection with another parasite or false-negative PCR results. Although the high prevalence of $P$. minibicornis in these

Table 3. Parvicapsula minibicornis in post-spawned coho salmon Oncorhynchus kisutch, chinook salmon O. tshawytscha and pink salmon O. gorbuscha collected from the Fraser River Drainage basin. PCR: number of kidney samples from which 1091 bp product was amplified. Negative, faint and strong refer to the detectability or relative intensity of the amplicon in ethidium bromide stained gels. Severity: mean number of infected glomeruli per 25 glomeruli examined from infected fish

\begin{tabular}{|c|c|c|c|c|c|c|c|}
\hline \multirow[t]{2}{*}{ Species } & \multirow[t]{2}{*}{ Location } & \multirow{2}{*}{$\begin{array}{c}\text { Sample } \\
\text { size }\end{array}$} & \multicolumn{3}{|c|}{ PCR } & \multicolumn{2}{|c|}{ Histology } \\
\hline & & & Negative & Faint & Strong & No. infected & Severity \\
\hline Coho & Deadman Creek & 10 & 0 & 0 & 10 & 7 & 2.1 \\
\hline Coho & Coldwater River & 10 & 0 & 0 & 10 & 6 & 1.3 \\
\hline Coho & Salmon River & 10 & 0 & 0 & 10 & 7 & 1.9 \\
\hline Chinook & Chilliwack River & 20 & 8 & 1 & 11 & 0 & 0 \\
\hline Chinook & Chehalis River & 20 & 11 & 8 & 1 & 4 & 2.0 \\
\hline Pink & Fraser River & 20 & 1 & 0 & 19 & 17 & 3.7 \\
\hline
\end{tabular}


populations favoured the latter possibility, at least 3 other genera of myxozoa are known to parasitise the kidney of sockeye salmon in British Columbia (McDonald \& Margolis 1993).

The patterns of distribution and prevalence of Parvicapsula minibicornis in migrating Fraser River sockeye in 2001 were similar to those observed in 1999 and 2000 (St. Hilaire et al. 2002). Infections in both Early groups and in the Summer group adult sockeye were not evident either at sea or prior to several $100 \mathrm{~km}$ of in-river migration. Transmission of the parasite to salmon has been hypothesized to occur in the lower river or estuary (St-Hilaire et al. 2002). While cageexposure studies using juvenile naïve salmonids confirmed that transmission occurs at the river mouth and approximately $10 \mathrm{~km}$ upstream (S. Jones unpubl.), additional research is necessary to fully identify the limits of this area. Failure to detect the parasite until several days after river entry is probably due to the low numbers of developing parasites that are present immediately following transmission. PCR detected $P$. minibicornis earlier than histological examination of kidney in a significant number of salmon, as reported earlier by St-Hilaire et al. (2002). Therefore the initially high numbers of false-negative histological results from both Early groups and from Summer group sockeye were likely due to the relative insensitivity of this method in detecting early infections. It follows that subsequent increases in prevalence and severity observed in both stocks were the result of the proliferative development of the parasite. Infection with $P$. minibicornis, measured by prevalence, severity or the rate of false-negative histological diagnosis, may therefore provide a useful measure of time elapsed since transmission within a migrating population, in this case equated with time since the salmon reentered the Fraser River. To fully develop this relationship, however, further research is necessary to better understand the factors that affect the rate of parasite development.

The overall high prevalence and relatively low rates of false-negative histology among sockeye salmon collected from the Harrison River were similar to those observed in both Early groups and in Summer groups after 600 to $700 \mathrm{~km}$ migrations, despite the relatively short distance $(\sim 110 \mathrm{~km})$ between the Harrison River and the Fraser River estuary. Together, these observations suggested that more time had elapsed since parasite transmission than would be predicted based on migration distance alone. This further supported the view that the severity of Parvicapsula minibicornis infection was exacerbated in some stocks by prolonged river residence times before spawning due to their premature migration into the river (Raverty et al. 2000, St-Hilaire et al. 2002). Weaver Creek is one of several Late run- timing stocks that has experienced premature river entry dates since 1995 (Pacific Salmon Commission 2001). This early migratory behaviour prolongs river residency, since dates of spawning have not changed. The present data also suggest, however, that a proportion of this stock retained an historical pattern of migration with typical river residence times. The initial absence of detectable infection among Weaver Creek stock sockeye suggested that any delay in migration since entering the Fraser River had been minimal for the first salmon of this stock to be captured in the Harrison River. Subsequent increases in prevalence and severity within the Weaver stock indicated a progressive increase in the period of freshwater residence. Thus, Weaver Creek sockeye that were late entering the Fraser River appeared to migrate with less delay into the Harrison River, evidently ahead of some of the same stock that had entered the Fraser River earlier. Whether the spawning success of the relatively less infected early migrants differed from that of the more heavily infected later migrants, however, was not determined here. The significantly lower severity of infection among Harrison stock sockeye probably related to the last collection from this stock (on September 29) being made approximately $44 \mathrm{~d}$ before peak spawning (November 11 to 15). The apparent fluctuations in severity observed in Harrison stock sockeye were due to small sample sizes (e.g. September 13 and 20).

Infection with Parvicapsula minibicornis in pink salmon represents a new host record. In addition, the use of PCR confirmed for the first time the identity of the parasite in coho salmon as $P$. minibicornis. These fish were mature adults collected at or near the spawning grounds and in most cases had already spawned. The occurrence of parasite stages in the glomeruli of $85 \%$ of PCR-positive pink salmon suggested that parasite development was similar to that in sockeye. The high proportion of glomerular infections in coho salmon also suggested similar tissue tropism and development in this host species. In contrast, $P$. minibicornis was rarely detected by histological examination in chinook salmon. Thus, sockeye and pink salmon were evidently the more suitable host species for $P$. minibicornis, followed by coho salmon. The failure of the parasite to develop infections within the glomeruli in most chinook salmon indicated that while susceptible, this species is not a suitable host. Undescribed Parvicapsula species have been reported from wild and farmed coho salmon in British Columbia and from net pen reared coho salmon in Puget Sound, Washington (USA) (Hoffman 1984, Johnstone 1984, Kent 1998). Johnstone (1984) also reported Parvicapsula sp. in farmed chinook salmon, cherry salmon Oncorhynchus masou, Atlantic salmon Salmo salar and cutthroat trout $S$. clarki in Puget Sound. The specificity of the PCR 
used in the present study suggested that the parasites previously observed in coho and chinook salmon were P. minibicornis.

Parvicapsula minibicornis has been associated with significant pre-spawning mortality among certain Late run-timing stocks of Fraser River sockeye (for example Weaver Creek and Cultus Lake) (St-Hilaire et al. 2002), which entered the Fraser River earlier than normal (Pacific Salmon Commission 2001). The occurrence of this parasite in adult pink, coho and chinook salmon from the Fraser River suggested that under appropriate conditions some or all of these species may also be at risk to elevated pre-spawn mortality associated with $P$. minibicornis. Further study to understand factors contributing to the pathogenicity of $P$. minibicornis in its various hosts is warranted.

Acknowledgements. The authors thank the Pacific Salmon Commission, staff from FOC Stock Assessment Division, Chilliwack River Hatchery, and Chehalis River hatchery for sampling assistance. We also thank Chehalis First Nation, Caribou Tribal Council, Lheidli T'enneh and Tl'azt'en Nation for their support of this research program. We thank Mr. Jim Woodey for reviewing an early draft of this manuscript.

\section{LITERATURE CITED}

Evdokimova EB (1977) Myxosporidians of teleost fishes from the Patagonian shelf (the Atlantic coast of Argentina). Parazitologiya 11:166-178

Gable J, Cox-Rogers S (1993) Stock identification of Fraser River sockeye salmon: methodology and management application. Pacific Salmon Commission Technical Report 5, Pacific Salmon Commission, Vancouver

Hoffman GL (1984) Two fish pathogens, Parvicapsula sp. and Mitraspora cyprini Myxosporea, new to North America. Symp Biol Hung 23:127-135

Humason GL (1979) Animal tissue techniques. WH Freeman, San Francisco

Johnstone AK (1984) Pathogenesis and life cycle of the myx-

Editorial responsibility: Wolfgang Körting,

Hannover, Germany osporean Parvicapsula sp. infecting coho salmon. PhD dissertation, University of Washington, Seattle

Kabata Z (1962) Five new species of Myxosporidia from marine fishes. Parasitology 52:177-186

Kent ML (1998) Protozoa and Myxozoa. In: Kent ML, Poppe TT (eds) Diseases of seawater netpen-reared salmonid fishes. Fisheries and Oceans, Nanaimo, p 49-67

Kent ML, Whitaker DJ, Dawe SC (1997) Parvicapsula minibicornis n. sp. (Myxozoa, Myxosporea) from the kidney of sockeye salmon (Oncorhynchus nerka) from British Columbia, Canada. J Parasitol 83:1153-1156

Kovaleva AA, Gaevskaya AV (1981) On new findings of Myxosporidia of the genus Parvicapsula in the Atlantic fishes. Zool Zh 60:771-773

Landsberg JH (1993) Kidney myxosporean parasites in red drum Sciaenops ocellatus (Sciaenidae) from Florida, USA, with a description of Parvicapsula renalis n. sp. Dis Aquat Org 17:9-16

Lester RJG, Sewell KB (1989) Checklist of parasites from Heron Island, Great Barrier Reef. Aust J Zool 37:101-128

McDonald TE, Margolis L (1993) Synopsis of the parasites of fishes of Canada: supplement (1978-1993). National Research Council of Canada, Ottawa

Pacific Salmon Commission (2001) Report of the Fraser River panel to the Pacific Salmon Commission on the 1999 Fraser River sockeye and pink salmon fishing season. Pacific Salmon Commission, Vancouver

Padma-Dorothy K, Kalavati C (1993) Parvicapsula hoffmani sp. n. (Myxozoa: Parvicapsulidae) from the mullet, Liza macrolepis (Smith). Acta Protozool 32:123-125

Raverty S, Kieser D, Bagshaw J, St-Hilaire S (2000) Renal infestation with Parvicapsula minibicornis in wild sockeye salmon from the Harrison and Adams rivers in British Columbia. Can Vet J 41:317-318

Shulman SS (1953) New and little known Myxosporidia from the White Sea. Zool Zh 32:384-393

St-Hilaire S, Boichuk M, Barnes D, Higgins M and 5 others (2002) Epizootiology of Parvicapsula minibicornis in Fraser River sockeye salmon, Oncorhynchus nerka (Walbaum). J Fish Dis 25:107-120

Zhao Y, Ma C, Song W (2000) Description of two new species of Parvicapsula Shulman, 1953 (Myxosporea: Parvicapsulidae) parasitic in the urinary bladder of marine fishes, Paralichthys olivaceus and Kareius bicoloratus, from the coast of the Yellow Sea, China. Acta Protozool 39:157-162

Submitted: July 1, 2002; Accepted: November 27, 2002

Proofs received from author(s): February 13, 2003 